\title{
Millennial-scale oscillations in the Kuroshio- Oyashio boundary during MIS 19 based on the radiolarian record from the Chiba composite section, central Japan
}

Takuya Itaki ${ }^{1^{*}}$, Sakura Utsuki ${ }^{1,2}$, Yuki Haneda ${ }^{1,3}$, Kentaro Izumi ${ }^{2}$, Yoshimi Kubota ${ }^{4}$, Yusuke Suganuma ${ }^{3,5}$ and Makoto Okada ${ }^{6}$

\begin{abstract}
Marine isotope stage (MIS) 19 is considered to be the best orbital analog for the present interglacial. Consequently, clarifying the climatic features of this period can provide us with insights regarding a natural baseline for assessing future climate changes. A high-resolution radiolarian record from 800 to $750 \mathrm{ka}$ (MIS 20 to MIS 18) was examined from the Chiba composite section (CbCS) of the Kokumoto Formation, including the Global Boundary Stratotype Section and Point for the lower-middle Pleistocene boundary on the Boso Peninsula on the Pacific side of central Japan. Millennial-scale oscillations in the Kuroshio warm and Oyashio cold currents were revealed by the Tr index, which is estimated using a simple equation based on radiolarian assemblages. The estimated $\operatorname{Tr}$ values ranged between 0.1 and 0.8 for MIS 18 through MIS 19, with minimum and maximum values corresponding to values observed off present day Aomori $\left(41^{\circ} \mathrm{N}\right)$ and the Boso Peninsula $\left(35^{\circ} \mathrm{N}\right)$, respectively. The observed patterns tended to be synchronous with the total radiolarian abundance associated with their production. Multiple maxima in radiolarian abundance occurred during periods of the Oyashio expanded mode before $785 \mathrm{ka}$ and during periods of Kuroshio extension after $785 \mathrm{ka}$ in MIS 19. Such increases in radiolarian abundance with the Kuroshio extension during MIS 19 are likely related to improvements in nutrient and photic environments with the development of a two-layer structure along the Kuroshio-Oyashio boundary zone. A similar pattern of millennial-scale climatic changes was also recognized in a precipitation record from the Sulmona Basin in central Italy, suggesting a close relationship with the CbCS record as a result of a large-scale climate system similar to the Arctic Oscillation in the northern hemisphere.
\end{abstract}

Keywords: Paleoceanography, Lower-Middle Pleistocene GSSP, Interglacial, MIS 19, Tr index, Teleconnection

\section{Introduction}

Marine Isotope Stage (MIS) 19 is almost at the midpoint of a transition between progressive increases in the amplitude of climate oscillations with a shift in periodicity from a 41-ky rhythm to a quasi-100 ky rhythm that occurred 1400-400 ka, known as the Early-Middle

\footnotetext{
*Correspondence: t-itaki@aist.go.jp

${ }^{1}$ Geological Survey of Japan/AIST, Institute of Geoinformation and Geology, 1-1-1 Hihashi, Tsukuba, Ibaraki 305-8567, Japan Full list of author information is available at the end of the article
}

Pleistocene transition (EMPT) (e.g., Head and Gibbard 2015). Global climatic changes through the EMPT, including MIS 19, were modulated by astronomical forcing and led to changes in the intensity of the Atlantic meridional overturning circulation (AMOC) (Hodell et al. 2008; Kleiven et al. 2011) and global sea levels (Elderfield et al. 2012). Furthermore, MIS 19 has been intensively studied because it is the best orbital analog for the present interglacial (e.g., Tzedakis et al. 2012). MIS 19 is characterized by a reduced-amplitude 400-ky eccentricity cycle and consequent suppression of precessional 
forcing. Although this orbital configuration is similar to MIS 11 and the present interglacial (MIS 1), only MIS 19 and 1 show an obliquity peak and the precession minimum in-phase (Tzedakis 2010). Therefore, it is important to obtain a detailed understanding of the climatic features of this period, as doing so could provide insights for establishing a natural baseline for assessing future climate changes (e.g., Tzedakis et al. 2012; Giaccio et al. 2015; Sánchez Goñi et al. 2016; Suganuma et al. 2018; Head 2021).

High-resolution paleoclimatic records during MIS 19 have been documented for the North Atlantic (Kleiven et al. 2011; Ferretti et al. 2015; Sánchez Goñi et al. 2016), Indian Ocean (Valet et al. 2014), southern Europe (Giaccio et al. 2015; Simon et al. 2017; Nomade et al. 2019; Regattieri et al. 2019), Japan (Hyodo et al. 2017; Suganuma et al. 2018; Haneda et al. 2020), Lake El'gygytgyn (Wennrich et al. 2014), Lake Baikal (Prokopenko et al. 2006), and Antarctica (Jouzel et al. 2007). The amplitudes and timing of millennial-scale variations in these paleoclimatic records tend to be synchronized among areas, suggesting the existence of a global climatic teleconnection pattern (Tzedakis et al. 2012; Nomade et al. 2019; Haneda et al. 2020). In order to clarify the mechanisms underlying the development of such a pattern, performing high-resolution reconstructions of the paleoenvironment in various areas of the world is necessary.

The Kazusa Group, which is composed of Pleistocene deep-sea deposits, is continuously distributed on the Boso Peninsula on the Pacific side of central Japan (e.g., Kazaoka et al. 2015). The area is unique in that, despite their relatively young age, the deep-sea outcrops are exposed on land as a result of active uplifting. Therefore, the sections comprising this group are well suited for studies of Pleistocene environmental changes. Furthermore, the Chiba composite section (CbCS) of the Kokumoto Formation in this group is well exposed and has a continuous marine sedimentary record across MIS 19 (Fig. 1), which has been extensively investigated (GSSP Proposal Group 2019; Suganuma et al. 2015; Nishida et al. 2016; Okada et al. 2017; Simon et al. 2019; Haneda et al. 2020; Izumi et al. 2020; Kameo et al. 2020; Kubota et al. 2021). The CbCS has been ratified by the International Commission on Stratigraphy as a Global Boundary Stratotype Section and Point (GSSP) for the Lower-Middle Pleistocene boundary.

At present, the offshore area near the Boso Peninsula is influenced by both the Kuroshio warm and Oyashio cold currents and, therefore, it is expected to be sensitive to both glacial-interglacial cycles and even small climatic changes in East Asia. Suganuma et al. (2018) discussed the close relationship between climatic changes in this area and climatic dynamics in East Asia based on the results of various proxies from the CbCS. Recently, more detailed millennial-scale studies from this section have been conducted on oxygen isotopes in foraminifera (Haneda et al. 2020), the geochemical record (Izumi et al. 2021), and calcareous nanofossils (Kameo et al. 2020). Kubota et al. (2021) discussed the dominant patterns in temporal variations in marine conditions using a principal component analysis (PCA) based on multiple proxies from geochemical and microfossil assemblages in the CbCS. The findings of these studies showed that millennial-scale changes in a variety of palaeoceanographic records from the CbCS likely reflect fluctuations in the Kuroshio-Oyashio boundary around the Boso peninsula and that these fluctuations may be linked to global teleconnection patterns.

Radiolarians, a marine plankton group with opaline (siliceous) skeletons, are preserved as microfossils in deep-sea sediments and are widely used as a paleoceanographic proxy. Radiolarian fossils are widespread in sediments of the North Pacific, even below the carbonate compensation depth (CCD) where calcareous microfossils are poorly represented. Consequently, the relation between radiolarian faunal distribution and oceanic conditions has been examined more extensively than it has for other microfossils (e.g., Nigrini 1970; Matsuzaki and Itaki 2017). Examination of this microfossil group is well suited for detecting changes in the Kuroshio-Oyashio front that are closely related to past climatic changes around the Boso Peninsula (e.g., Chinzei et al. 1987; Yasudomi et al. 2014). Furthermore, radiolarian fossils can be used as a proxy for not only surface environments, but also for deep water masses because of differences in habitat preference among species (e.g., Matsuzaki and Itaki 2017). The radiolarian fossil record is thus a robust paleoceanographic tool in studies of the CbCS.

A total of 36 radiolarian species and species groups have been reported for the CbCS (Motoyama et al. 2017), and radiolarian assemblages related to climatic changes have been reported by Suganuma et al. (2018); however, the inclusion of few species meant that their results were considered to be low-resolution and preliminary. In order to provide more accurate interpretations of paleoceanographic phenomena, more detailed changes in radiolarian assemblages and their abundance are required. Therefore, in this study, we conducted a high-resolution analysis of millennial-scale changes in the KuroshioOyashio system during MIS 19 based on radiolarian fossil records from the CbCS.

\section{Methods}

A total of 236 radiolarian samples, including 195 new samples and 41 samples that were used for preliminary analysis by Suganuma et al. (2018), were analyzed in this 

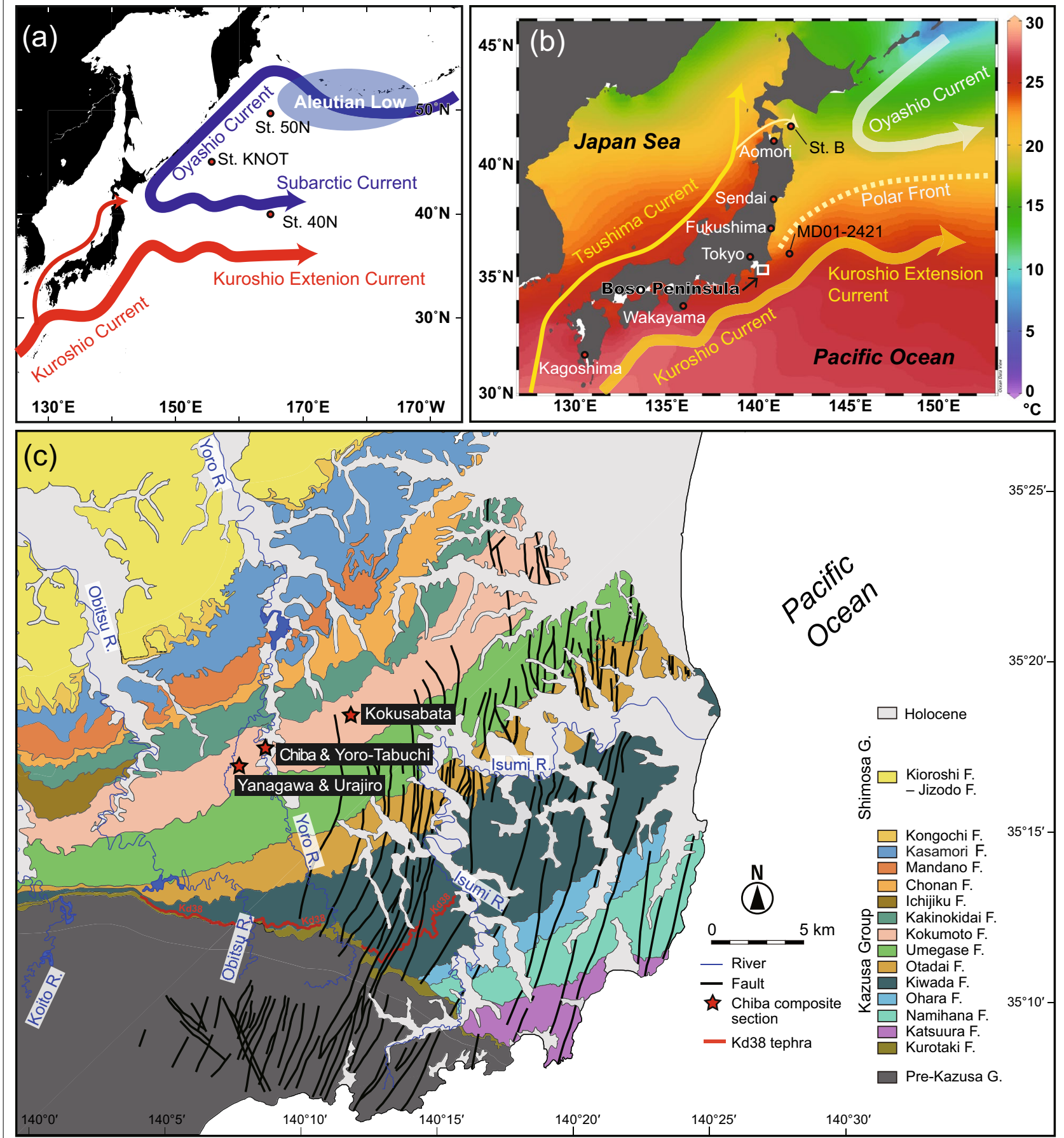

Fig. 1 Maps showing a major ocean currents around Japan, b summer sea-surface temperatures around the Boso Peninsula, and $\mathbf{c}$ simplified geological map (Kazaoka et al. 2015). Red stars in (c) indicate locations of the Urajiro, Yanagawa, Yoro River, Yoro-Tabuchi, and Kokusabata sections that comprise the Chiba composite section (CbCS)

study (Additional file 1: Tables S1 and Additional file 2: Table S2). Of the 195 new samples, Kubota et al. (2021) used a subset of 63 samples for the radiolarian dataset in their study. Sampling locations, stratigraphic framework, and age models are based on Suganuma et al. (2018) and Haneda et al. (2020) (Additional file 3: Fig. S1).

Freeze-dried samples were weighed and wet sieved through $45 \mu \mathrm{m}$ meshes, and two types of slides were 
prepared to quantify abundance (Q-slide) and for faunal analysis (F-slide) using standard techniques described in Itaki et al. (2018). The level of preservation of the radiolarian fossils was judged as being good (majority of specimens complete, with no or minor dissolution, recrystallization, and/or breakage), moderate (minor, but common dissolution, with a small amount of breakage of specimens) or poor (strong dissolution, recrystallization, or breakage, many specimens unidentifiable).

The total number (abundance) of radiolarians in $1 \mathrm{~g}$ of dry sediment was estimated using the following equation:

$$
\begin{aligned}
& \text { Total radiolarian abundance (individuals/g) } \\
& =\text { total number of individuals on } \mathrm{Q} \text { - slide } \\
& \quad \times 200 / \text { sample weight }(\mathrm{g})
\end{aligned}
$$

The total radiolarian abundance was estimated for 193 of the 195 samples that were newly collected in this study; two samples were excluded from the analysis due to problems with Q-slide preparation.

For 153 of the 195 new samples, the relative abundance (percentage of total assemblage) of the species was estimated by counting and identifying more than 200 individuals on the F-slide. However, when radiolarian individuals were scarce, as many as could be identified were counted (Additional file 1: Table S1). Radiolarians were observed under an optical microscope at $40 \times$ to $200 \times$ magnification. Identifications were performed using a taxonomic framework adapted from Itaki (2009), Matsuzaki and Itaki (2017), and Matsuzaki et al. (2020). Photomicrographs of radiolarians from the $\mathrm{CbCS}$ are illustrated in Motoyama et al. (2017).

The $\operatorname{Tr}$ value, which is a radiolarian-based climate index originally proposed by Nigrini (1970), was calculated using the following equation:

$$
\operatorname{Tr}=\mathrm{Xw} /(\mathrm{Xw}+\mathrm{Xt}+\mathrm{Xc})
$$

where $\mathrm{Xw}, \mathrm{Xt}$ and $\mathrm{Xc}$ are the number of warm-, temperate- and cold-water radiolarian species and species groups, respectively.

Yanagisawa (1993) demonstrated that a similar climatic index based on diatoms (Td value) does not have the same sensitively to sea-surface temperatures in all oceanic regions; however, it can be used as a tracer for two different water masses originating from the warm and cold currents within the transitional zone of the currents. The same logic can be applied to the Tr value. For example, as shown in Fig. 2, latitudinal variation in the $\operatorname{Tr}$ value based on the dataset of Matsuzaki and Itaki (2017) shows that the polar front $(\operatorname{Tr}=\mathrm{ca} .0 .5)$, defined as the latitudinal zone showing the steepest $\operatorname{Tr}$ variation, is located at around $37^{\circ} \mathrm{N}$ off present-day Fukushima, and the Boso Peninsula is located within the transitional

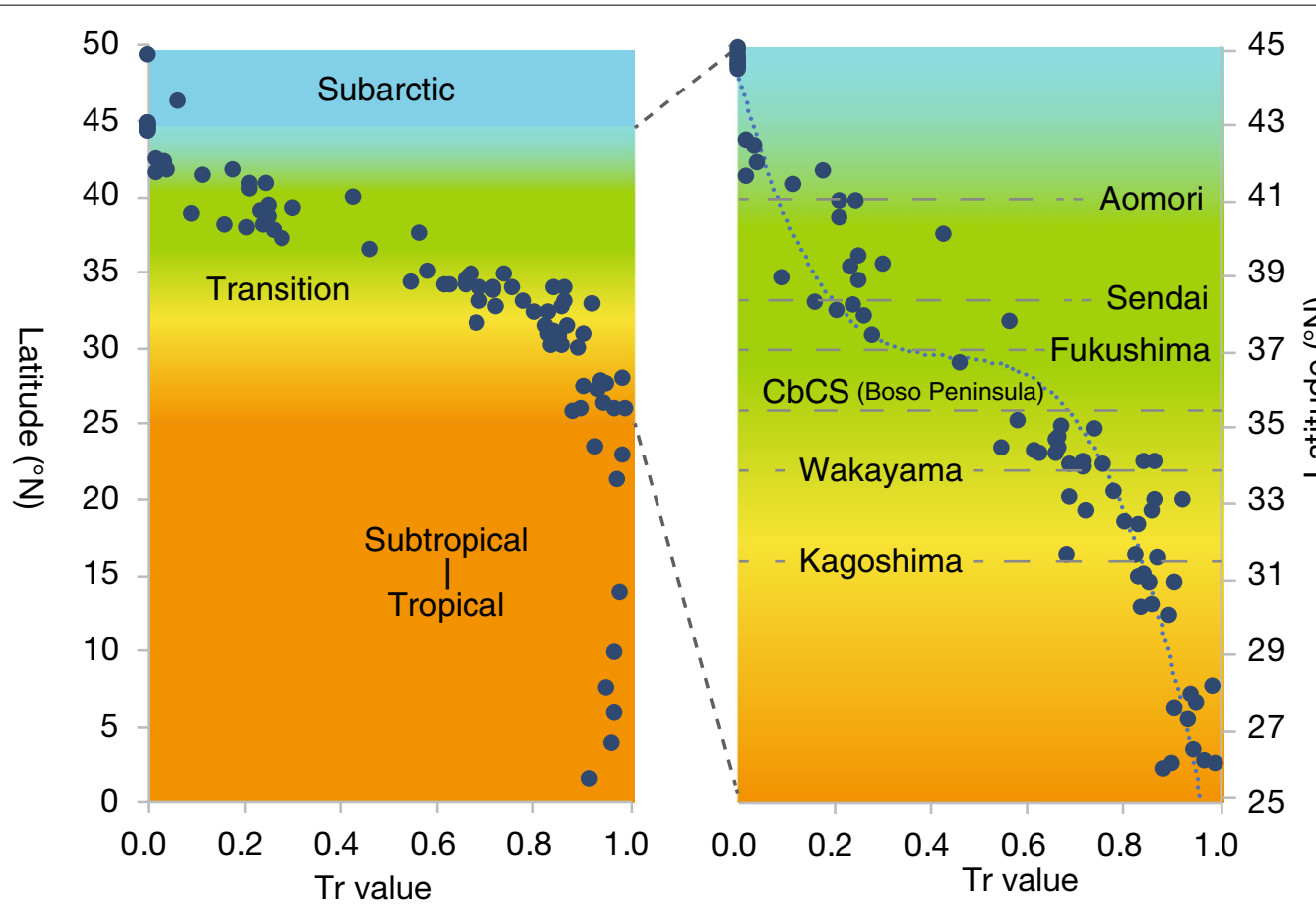

Fig. 2 Plot showing the latitudinal distribution of Tr values in the northwestern Pacific based on the dataset from Matsuzaki and Itaki (2017). Similar plots for each species or species groups used for the Tr estimation are shown in Additional file 5: Fig. S3 
zone of the Tr value due to mixing of the Kuroshio and Oyashio currents. On the other hand, values above 0.8 and below 0.2 show gradual slopes latitudinally, indicating that sensitivity to changes in water mass is low. Suganuma et al. (2018) applied Tr values to their preliminary results for 41 samples from the $\mathrm{CbCS}$ and obtained values in the sensitive interval between 0.2 and 0.8 . Therefore, this index can be used for assessing the relative contributions of the Kuroshio and Oyashio currents to the CbCS. The data used to estimate Tr values in this study and that of Suganuma et al. (2018) are given in Additional file 2: Table S2.

\section{Results}

Radiolarian fossils were observed in all of the analyzed samples. Preservation levels were moderate to good, and no modifications to the assemblage and/or abundance were observed. The number of radiolarian fossils in each sample ranged between 57 and 363 individuals (203 \pm 74.7 , average \pm standard deviation).

Figure 3 shows the temporal changes in total radiolarian abundance (individuals/g) and relative abundance (percentage of total assemblage) for 11 species/species groups in the new dataset from the CbCS. The total abundance ranged from 90 to 1220 individuals/g, and periodic fluctuations at 2400-, 2900-, and 5800-year intervals were observed over the period analyzed in the study (Fig. 3a, Additional file 6: Fig. S4). Multiple maxima and minima in the total radiolarian abundance tended to be synchronized with the absolute abundance (individuals/g) of several major species or species groups; however, these relationships were not significant for the relative abundance of the assemblage (\%) (Fig. 3b-n).

In this high-resolution analysis using 153 samples, a total of 30 species and species groups were identified (Additional file 1: Table S1). The most dominant radiolarian taxon was Tetrapyle circularis/fruticosa group sensu Matsuzaki et al. (2020), followed by Spongodiscus resurgens Ehrenberg, Larcopyle buetchlii Dreyer, Didymocyrtis tetrathalamus (Haeckel) group (including young form), and Lithomelissa setosa Jørgensen. As minor radiolarians, the Dictyocoryne profunda Ehrenberg / Dictyocoryne truncatum (Ehrenberg) group (including their young form), Stylochlamydium venustum (Bailey), Amphirhopalum ypsilon Haeckel, Druppatractus irregularis Popofsky, the Dictyocoryne elegans (Ehrenberg)/Dictyocoryne muelleri (Haeckel) group (including their young form), the Phorticium pylonium (Haeckel)/polycladum Tan and Tchang group, and Lithelius minor Jørgensen and Cycladophora davisiana Ehrenberg were also observed. Changes in the abundance of radiolarian fauna relating to associated with water masses were as follows.
Subtropical water fauna: the T. circularis/fruticosa group, the $D$. tetrathalamus group, the $D$. truncatum/profunda group, the A. ypsilon, P. pylonium /polycladum group, and the D. elegans/muelleri group are all subtropical species that are characteristic of the Kuroshio region where sea-surface temperatures range between 20 and $29{ }^{\circ} \mathrm{C}$ according to Matsuzaki and Itaki (2017). Radiolarians in this group accounted for 5-45\% of the assemblage in the CbCS and their abundance tended to be high during MIS $19 \mathrm{c}$ to $19 \mathrm{~b}$ and low in MIS 19a and MIS 20, except for the P. pylonium /polycladum group, which showed low abundance values during MIS 19c (Fig. 3b-g). Based on the results of a sediment trap study at Station B in a coastal region of the Oyashio in the western subarctic Pacific, Itaki et al. (2008) reported that these subtropical radiolarians are dominant in summer (see Fig. 1b).

Mixed water fauna: L. buetschlii, S. resurgens, and S. venustum accounted for 9-36\% of radiolarians in the $\mathrm{CbCS}$ and tended to show higher abundance in MIS 19b and MIS 20 (Fig. 3h-j). Matsuzaki and Itaki (2017) assigned these radiolarians to the "warm-temperate species" group, which are found in the mixing area of the Kuroshio and Oyashio waters between 16 and $23^{\circ} \mathrm{C}$. Sediment trap records at Station B in a coastal region of the Oyashio showed that flux peaks occur during spring for L. buetschlii and S. venustum, and in winter and spring for S. resurgens (Itaki et al. 2008).

Subarctic coastal water fauna: L. setosa accounted for $0-19 \%$ of radiolarians in the $\mathrm{CbCS}$, with abundance increasing significantly during MIS 19a and MIS 20 (Fig. 3k). Two short-period maxima also occurred in MIS 19; one in MIS 19b and the other in the middle of MIS 19c. This species is commonly encountered at temperatures ranging from 12 to $18{ }^{\circ} \mathrm{C}$ in the coastal regions of the Oyashio (Matsuzaki and Itaki, 2017) and in Norwegian fjords (Bjørklund, 1974). Further, this species was dominant in the assemblage from autumn to winter at Station B in the coastal region of the Oyashio (Itaki et al. 2008). The cold and low-salinity coastal Oyashio Current, which flows southwestward along the southeastern coast of Hokkaido in winter and spring, may originate from melting sea-ice in the Sea of Okhotsk (Kono et al. 2004).

Although Matsuzaki and Itaki (2017) categorized another group of "subarctic species" comprising species such as Ceratospyris borealis Bailey and Antarctissa? sp. 1 Nimmergut and Abelmann which are adapted to subarctic waters with temperatures of $7-12{ }^{\circ} \mathrm{C}$, these taxa were not encountered in the $\mathrm{CbCS}$, suggesting that the mainstream of the Oyashio Current flowing offshore has no influence on the faunal composition of this group.

Deep-dwelling taxa: D. irregularis, L. minor, and C. davisiana are known to be species that are mainly 


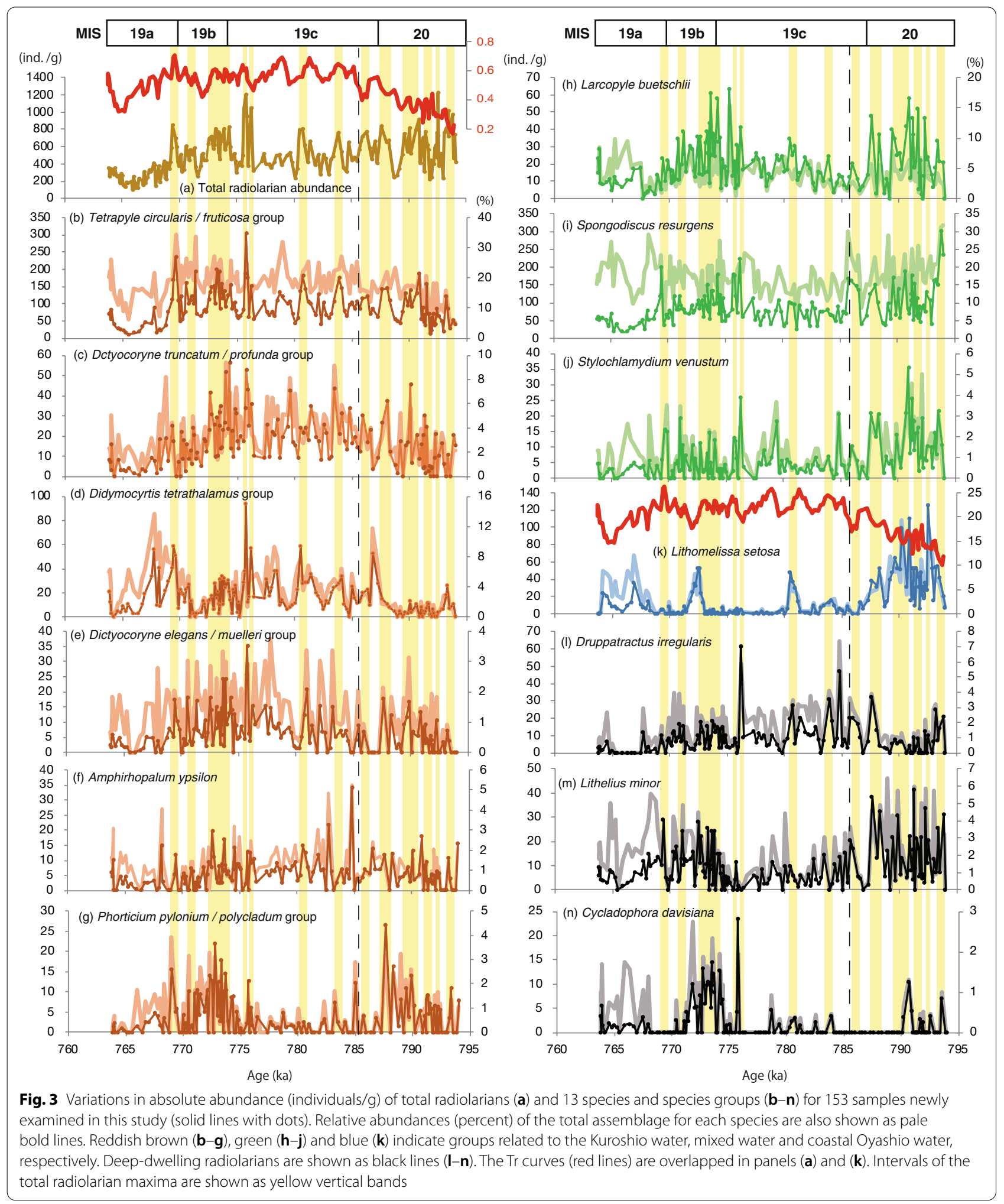


adapted to waters deeper than $200 \mathrm{~m}$ in the North Pacific (e.g., Matsuzaki et al. 2020). Interestingly, the occurrence patterns of these species differed from each other (Fig. 3l-n). The abundance of D. irregularis was relatively high during MIS 19b to MIS 19c and low in MIS 19a and MIS 20. Lithelius minor shows similar variations in abundance to the mixed-water fauna, with higher values observed in MIS 19b and MIS 20. Although C. davisiana is a minor species that accounts for less than $3 \%$ of the assemblage, its abundance increased in MIS 19a and MIS 19b (Fig. 3n). According to Matsuzaki and Itaki (2017), D. irregularis and L. minor are both deep dwellers that are adapted to mid-latitude regions in the North Pacific, while $C$. davisiana is found in intermediate to deep waters that originate from higher latitudes. Other deep dwelling taxa, such as Actinomma leptodermum (Jørgensen), Cornutella profunda Ehrenberg, Spongurus cylindricus Haeckel were also recognized in the CbCS; however, their abundance was low.

The $\operatorname{Tr}$ value was estimated based on the seven indicator species/species groups shown in Additional file 1: Table S2, which were also mentioned in Suganuma et al. (2018); these species/groups included the subtropical water (warm) group (T. circularis/fruticosa group, D. tetrathalamus group, and D. truncatum /profunda group), the subarctic coastal water (cold) group (L. setosa), and the mixed water (temperate) group ( $L$. buetschlii, S. resurgens and S. venustum). Figure 4 shows the temporal variations in the Tr value obtained for the 194 samples and the total radiolarian abundance in 234 samples estimated in this study and in Suganuma et al. (2018), together with the oxygen isotope ratio for planktonic foraminifera (Haneda et al. 2020). The radiolarian-based summer SST obtained from a new dataset comprising 153 samples is also shown in this figure.

The $\operatorname{Tr}$ value fluctuated considerably between 0.1 and 0.8 from MIS 20 to MIS 18, likely reflecting oscillations in the Kuroshio-Oyashio boundary throughout this period (Fig. 4). High Tr values are indicative of a large contribution from the Kuroshio Current, while low values reflect the influence of the Oyashio Current and Oyashio coastal waters. The range in $\operatorname{Tr}$ values $(0.1-0.8)$ recorded in the $\mathrm{CbCS}$ corresponds to latitudes from approximately $41^{\circ} \mathrm{N}$ (off present-day Aomori Prefecture) to $31^{\circ} \mathrm{N}$ (off present-day Kagoshima Prefecture) (Fig. 2). The current $\mathrm{Tr}$ value near the Boso Peninsula ( $\mathrm{CbCS}$ ) is approximately 0.6. Generally, higher values of between 0.4 and 0.8 with millennial-scale oscillations (periodicity $2.9 \mathrm{kyr}$, Additional file 6: Fig. S4) were observed during most of MIS $19 \mathrm{c}$ to $19 \mathrm{~b}$, and values below 0.4 were observed in MIS 20 and mid-MIS 19a. The multiple maxima in the Tr curve (shaded intervals in Fig. 4) tended to correspond with maxima and minima in total radiolarian abundance after and before $785 \mathrm{ka}$, respectively.

\section{Discussion}

\subsection{Millennial-scale fluctuations}

The observation of $\operatorname{Tr}$ values below 0.4 in MIS 20 and mid-MIS 19a imply that the CbCS was located under conditions similar to those of the present day Oyashio current north of $37^{\circ} \mathrm{N}$ (off present-day Fukushima Prefecture). On the other hand, distinct millennial-scale fluctuations in $\operatorname{Tr}$ values of between 0.4 and 0.7 (using three moving averages in Fig. 4) during MIS 19 clearly indicate the occurrence of Kuroshio/Oyashio oscillations. The lowest value corresponds to the polar front, while the highest value corresponds to values around $34^{\circ} \mathrm{N}$ (off present-day Wakayama Prefecture).

Although some discrepancies in the low-resolution record are recognized in MIS 20 and MIS 18, the observation of low and high variations in $\operatorname{Tr}$ values in the high-resolution record interval during MIS 20 and MIS 19, respectively, is generally consistent with largescale changes in the oxygen isotope ratio of planktonic foraminifera (e.g., Globigerina bulloides d'Orbigny $\left(\delta^{18} \mathrm{O}_{\mathrm{Gb}}\right)$ and Globorotalia inflata (d'Orbigny) $\left.\left(\delta^{18} \mathrm{O}_{\mathrm{Gi}}\right)\right)$, which corresponds to the glacial-interglacial cycles reported by Haneda et al. (2020) (Fig. 4a). Such similarities in the fluctuations of $\delta^{18} \mathrm{O}$ and Tr imply the existence of similar oceanic conditions, such as temperature and salinity. Since the radiolarians that are typically used to estimate $\operatorname{Tr}$ are usually distributed from the surface to the subsurface (ca. 0-200 m) regions of the water column, the Tr values tended to be more consistent with the general $\delta^{18} \mathrm{O}$ patterns obtained from $G$. bulloides and $G$. inflata, indicating that these species inhabited the surface and subsurface regions, respectively. The Tn values (nannofossil temperature index) that are characteristic of the surface conditions in the CbCS show a similar pattern to the large-scale changes in Tr values (Kameo et al. 2020).

However, in terms of millennial-scale changes with relatively small amplitudes, the Tr curve did not show any correspondence with $\delta^{18} \mathrm{O}$ values during early MIS 19c. For example, the Tr peaks seen during early MIS19c were not observed in the $\delta^{18} \mathrm{O}$ record. The changes in foraminifera $\delta^{18} \mathrm{O}$ are associated with changes in temperature and $\delta^{18} \mathrm{O}$ of seawater (mainly temperature in the case of the CbCS, according to Kubota et al. 2021), while the Tr variations might also be related to other conditions, such as salinity, nutrients, and water mass structure. In the Kuroshio-Oyashio boundary zone, changes in the water structure and their effect on nutrient conditions are complicated, and it is possible that such changes could account for the inconsistencies observed in $\delta^{18} \mathrm{O}$ 


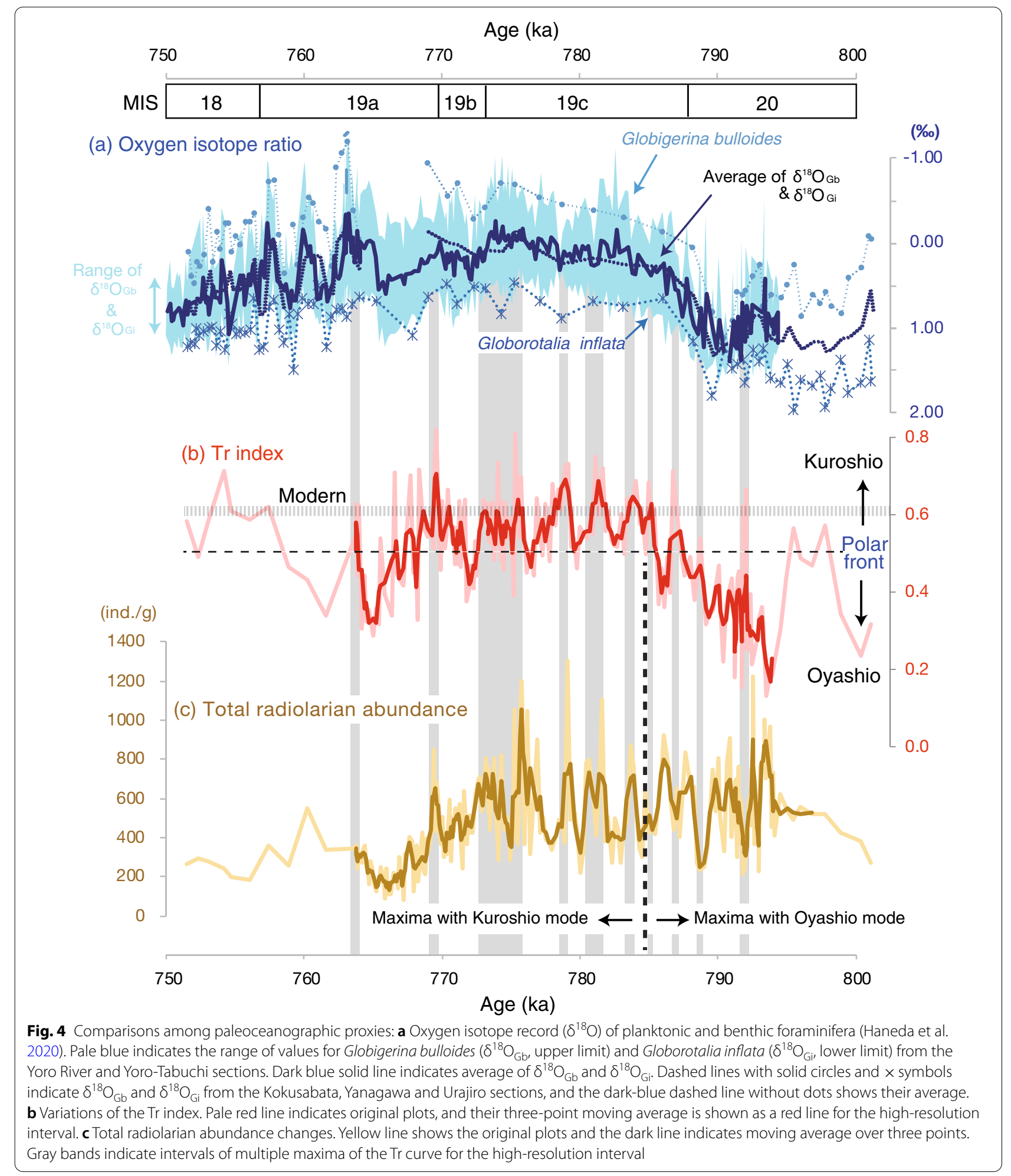

records in the high-resolution record. In other words, $\mathrm{Tr}$ can be regarded as an index for a variety of conditions that include surface/subsurface temperatures, nutrient conditions, and fluctuations in the water structure of the Kuroshio-Oyashio confluence. 
Inconsistencies between $\operatorname{Tr}$ and $\delta^{18} \mathrm{O}$ during early MIS 19c could also be attributed to differences in the ecology of the radiolarians used to estimate the $\mathrm{Tr}$ index. Although the radiolarian fauna of the Kuroshio Current show generally similar patterns, the detailed patterns of each species group are sometimes different; for example, while a peak in the abundance of the $D$. tetrathalamus group that was observed at the MIS 19/MIS 20 boundary corresponded with a peak in $\operatorname{Tr}$ values, the $D$. truncatum / profunda and T. circularis/fruticosa groups showed a decrease in abundance at that time. According to the results of a principal component analysis (PCA) based on multiple proxies from geochemical and microfossil assemblages in the CbCS (Kubota et al. 2021), the $\mathrm{PC} 1$ and $\mathrm{PC} 2$ components reflect surface and subsurface conditions, respectively, and PC3 is related to stratification structure of the upper waters. For example, the abundance of $L$. setosa, which is a coastal species of the Oyashio Current and is included in PC1, was closely related to the $\delta^{18} \mathrm{O}$ variations. For the warm-water radiolarians, the abundance of the $D$. tetrathalamus group showed a relatively strong correlation with PC1. PC2, which included the $D$. truncatum / profunda group, shows close relation to the G. inflata $\mathrm{Mg} / \mathrm{Ca}$ ratio as a proxy of the subsurface water temperature. $\mathrm{PC} 3$ is correlated with differences in the $\delta^{13} \mathrm{C}$ and $\delta^{18} \mathrm{O}$ values between G. bulloides and G. inflata, which were caused by the water column having a stratified structure. The radiolarian species S. resurgens and the T. circularis/fruticosa group show high loadings for PC3. Significant Tr variations during early MIS 19c, which is inconsistent with $\delta^{18} \mathrm{O}$ values, are probably associated with the subsurface and stratification conditions explained by PC2 and $\mathrm{PC} 3$ of small relation to the $\delta^{18} \mathrm{O}$ variations.

Another possible reason for the inconsistencies observed between the $\operatorname{Tr}$ and $\delta^{18} \mathrm{O}$ variations during early MIS 19c could be due to seasonal factors. Based on the findings of sediment trap experiments at Station B in coastal areas of the Oyashio Current, the contribution of the abundance of radiolarians in the Kuroshio group to the Tr index during MIS 19 increases during the summer to autumn (Itaki et al. 2008). On the other hand, $\delta^{18} \mathrm{O}$ and geochemical records of the planktonic foraminifera G. bulloides and G. inflata are interpreted as reflecting peaks in winter to spring in the Kuroshio-Oyashio mixed zone (Kubota et al. 2021). The utility of using the $\delta^{18} \mathrm{O}$ of G. bulloides as a winter proxy has been demonstrated by Sagawa et al. (2013) using sediment traps at station B. Therefore, multiple increases in the Tr values during MIS 19c were possibly associated with Kuroshio extension during summer to autumn, and such signals were not recognized/ in the winter-spring records of planktonic $\delta^{18} \mathrm{O}$.
Millennial-scale Kuroshio-Oyashio fluctuations during the interglacial stage have also been reported from other interglacial periods. Holocene 1500-year cycles in SST fluctuations have been reported based on the $\mathrm{Uk}^{37}$ index (Isono et al. 2009) and diatom fossil assemblages (Koizumi, 2008) from a marine sedimentary core (MD01-2421) collected from the western Pacific at $36^{\circ} \mathrm{N}$ near the Boso Peninsula. In those studies, the amplitude of the fluctuation in water temperature was estimated to be about $1{ }^{\circ} \mathrm{C}$. Yasudomi et al. (2014), who conducted a detailed examination of the radiolarians of the last interglacial period (MIS-5e) using the same core, showed that the $\mathrm{Tr}$ value fluctuated with a 500-year cycle. The $\mathrm{Tr}$ values in their study $(0.6-0.9)$ were slightly higher than results from the $\mathrm{CbCS}$ in this study, implying that the water temperatures in the Holocene and MIS-5e were likely higher and showed smaller fluctuations than those in MIS 19.

\subsection{Relation of water structure to radiolarian ecology}

Changes in water masses affect not only radiolarian assemblages, but also their productivity. It is generally considered that the abundance of radiolarians preserved in sediments reflects the productivity of the water column; however, other factors can also affect the distribution of radiolarian fossils in sediments, including dilution by terrigenous material and dissolution of radiolarian skeletons during diagenesis. In this study, we assumed that radiolarian abundance is correlated with productivity, because the effects of extreme dissolution and dilution are likely to be small given the minor changes observed in the dissolution index and sedimentary facies. Below, we discuss changes in productivity under different radiolarian ecological settings in the Kuroshio-Oyashio boundary zone observed in the CbCS.

Radiolarians in the oceanic ecosystem occupy the trophic level of secondary producers. In terms of feeding strategies, radiolarian taxa can be herbivorous, omnivorous, or employ symbiotic photosynthetic algae or cyanobacteria. Consequently, changes in total radiolarian abundance in the CbCS could be reflected by factors that affected their feeding ecology. According to Zhang et al. (2018), who examined living radiolarians in the North Pacific epifluorescence microscopy, 37 radiolarian taxa living in the Kuroshio region, such as the T. circularis/fruticosa group and the D. tetrathalamus group, depend on symbiosis with photosynthetic algae for their nutrition. On the other hand, L. setosa, S. resurgens and S. venustum, which are distributed in the Oyashio region, do not have symbiotic photosynthetic algae, suggesting that these species are either herbivorous or omnivorous. Thus, factors that affect radiolarian production are likely 
to be reflected in the trophic structure of radiolarians in specific water mass environments.

The question is what factors can be used to infer millennial-scale variations of total radiolarian abundance in the CbCS. According to Okazaki et al. (2005), who collected radiolarians in time-series experiments using sediment traps deployed at three stations $(50 \mathrm{~N}, \mathrm{KNOT}$, and $40 \mathrm{~N}$ ) in the northwestern Pacific (see Fig. 1a for locations), the correlation coefficients between total radiolarian flux and total mass flux (closely related to diatom flux) were relatively high at Station $40 \mathrm{~N}$ in the KuroshioOyashio Extension $(r=0.68)$ compared to those sampled at the other two subarctic stations (KNOT: $r=0.43$ and $50 \mathrm{~N}: r=0.44)$. Their findings suggested that the relationship between radiolarian production and primary production is not straightforward, primarily because of the wide vertical distribution and various trophic patterns observed in radiolarians.

The millennial-scale maxima in total radiolarian abundance tends to coincide with warmer and cooler intervals that appeared after and before $785 \mathrm{ka}$, respectively (Fig. 4). The timing of this shift corresponds to a change from Oyashio-dominant conditions to Kuroshio-dominant conditions. In other words, increases in radiolarian productivity occurred during the period when $\operatorname{Tr}$ was below 0.5 before $785 \mathrm{ka}$, and during the period when $\mathrm{Tr}$ was above 0.6 after $785 \mathrm{ka}$. The Tr value of 0.5 that distinguishes the Kuroshio- and Oyashio-dominant conditions is defined by a steep latitudinal gradient in $\mathrm{Tr}$ values, indicating the existence of a boundary at that time between the two water masses off present-day Fukushima (Fig. 2). This region corresponds to the polar frontal zone, which is characterized by having a summer SST of approximately $23{ }^{\circ} \mathrm{C}$ and nutrient-rich Oyashio waters distributed to the north (Fig. 1b). The high radiolarian abundance observed during cooler intervals at the end of MIS 20 and early MIS 19 is likely to have been affected by the high nutrient supply from the Oyashio water with a southward shift in the polar front (Oyashio expanded mode, Fig. 5a). This southward shift in the polar front, in turn, probably occurred in response to the southward shift of the westerly jet with the intensification of the winter Aleutian Low, as discussed in Suganuma et al. (2018), Haneda et al. (2020), and Kubota et al. (2021).

On the other hand, the multiple maxima observed in radiolarian productivity during the warm MIS 19 tended to correspond with Tr maxima above 0.6, here defined as the Kuroshio expanded mode. The Kuroshio neutral mode is defined as Tr values between 0.5 and 0.6 without any corresponding maxima in radiolarian productivity after $785 \mathrm{ka}$. The millennial-scale fluctuations in the $\mathrm{Tr}$ value and radiolarian productivity during MIS 19 can be explained by changes in the water structure
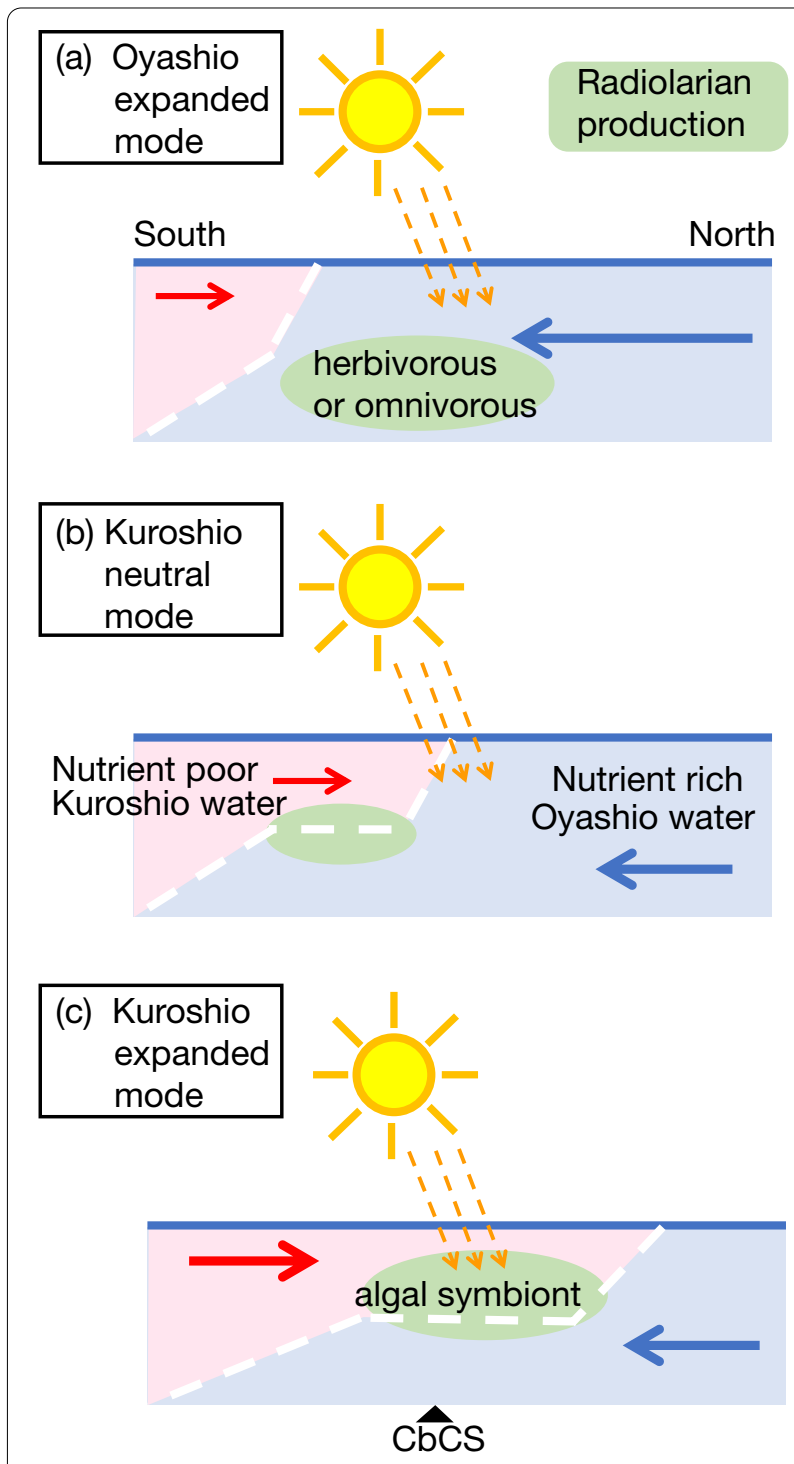

Fig. 5 Schematics of oceanographic conditions indicating a Oyashio expanded mode, likely present in late MIS 20 and characterized by high radiolarian productivity, and $\mathbf{b}$ neutral mode in MIS 19, when the Kuroshio-Oyashio layered structure was contracted, and c same conditions, but with Kuroshio extended mode when the layer structure was extended

associated with oscillations in the Kuroshio neutral and expanded modes (Fig. 5b, c). Nishibe et al. (2015) proposed that high primary productivity can be attributed to the development of favorable conditions for photosynthesis when the warm Kuroshio water overlays the cold Oyashio water. In addition, the areal extent of the Kuroshio-Oyashio layered structure varies from year to year, and this interannual variability affects primary productivity, making it possible to relate these variations to inter-decadal shifts in the climate regime of the North 
Pacific (Nishikawa et al. 2016). Favorable conditions for photosynthesis are also required by radiolarians with algal symbionts in the Kuroshio region, such as the T. circularis/fruticosa group (Zhang et al. 2017), which is the most important radiolarian group in terms total radiolarian abundance in the CbCS. In addition, the abundance variations in radiolarians with algal symbionts are correlated with the stratification component (PC3) of Kubota et al. (2021). Therefore, the millennial-scale variations observed in radiolarian productivity in the $\mathrm{CbCS}$ during MIS 19 are likely the result of the expansion and retreat of the Kuroshio-Oyashio layered structure (Fig. 5b, c).

\subsection{Possible teleconnection}

Recent studies have demonstrated that paleoclimate and paleoceanographic changes recorded in the CbCS were linked to global-scale variations in climate (Suganuma et al. 2018; Haneda et al. 2020; Kubota et al. 2021). In this section, the possible relationship between the variation in $\mathrm{Tr}$ values in the $\mathrm{CbCS}$ and changes in paleoclimate records from southern Europe due to the Arctic Oscillation $(\mathrm{AO})$ is discussed.

As discussed in the preceding section, the correspondence between millennial-scale maxima in radiolarian productivity and $\mathrm{Tr}$ peaks during the Kuroshio mode after 785 ka were likely related to the development of the Kuroshio-Oyashio layered structure. On the other hand, fluctuations in the abundance of L. setosa are considered to be influenced by the East Asian Winter Monsoon (EAWM), which, according to the PCA results of Kubota et al. (2021), is affected by the intensity of the Aleutian Low. In actuality, L. setosa records information during the winter season according to its seasonal productivity in the coastal Oyashio region (Itaki et al. 2008). Significant increases in L. setosa abundance during MIS 19a, MIS 19b, and MIS 20 are coincident with decreases of the $\operatorname{Tr}$ values, suggesting that the influence of the EAWM is strong during the Oyashio expanded mode. Two minor increases in $L$. setosa abundance at $781 \mathrm{ka}$ and $784 \mathrm{ka}$ tended to overlap with high $\mathrm{Tr}$ values. Such a condition could be attributed to Kuroshio transport increasing when the Aleutian Low intensifies (Deser et al. 1999). These dynamics may also explain the inconsistencies observed between $\operatorname{Tr}$ values and planktonic $\delta^{18} \mathrm{O}$ during MIS 19c, when the Tr maxima were associated with Kuroshio expansion during summer to autumn, while planktonic $\delta^{18} \mathrm{O}$ records were associated with winterspring signals.

Millennial-scale climatic changes observed during MIS 19 have also been reported for the northern Atlantic Ocean (Kleiven et al. 2011) and central Europe (Giaccio et al. 2015; Sánchez Goñi et al. 2016; Regattieri et al. 2019). Figure 6 shows a possible correlation between climate records for the Sulmona Basin in central Italy (Giaccio et al. 2015; Regattieri et al. 2019) and the CbCS in Japan (this study). Oxygen isotope records for endogenic calcite from the Sulmona Basin can be used as a proxy for precipitation amount, with lower values reflecting increased precipitation and higher values reflecting a reduction in precipitation.

Synchronous trends in each of these regions during MIS 19 suggest the existence of a large-scale teleconnection over the northern hemisphere, not unlike the effect of the Arctic Oscillation (AO) (or North Atlantic Oscillation, NAO) on the intensity of the winter Aleutian Low (Tompson and Wallace 1998). It is considered that the wet (dry) conditions in southern Europe during MIS 19 were caused by the southern (northern) shift of westerly storm tracks during the negative (positive) phase of the AO/NAO (Regattieri et al. 2019). On the other hand, the Kuroshio transport increases (decreases) with the intensification of the Aleutian Low during the negative (positive) AO (Deser et al. 1999), and such a situation is expected to have occurred during MIS 19, based on the radiolarian record discussed above. As shown in Fig. 6, a consistent relationship is seen between paleo-records of humidity in central Italy and the Kuroshio expansion in the CbCS during MIS 19. This hypothesis does not contradict the teleconnection mechanism proposed by Haneda et al. (2020), in which millennial-scale latitudinal oscillations of the Kuroshio Extension Front (KEF) during the late MIS 19

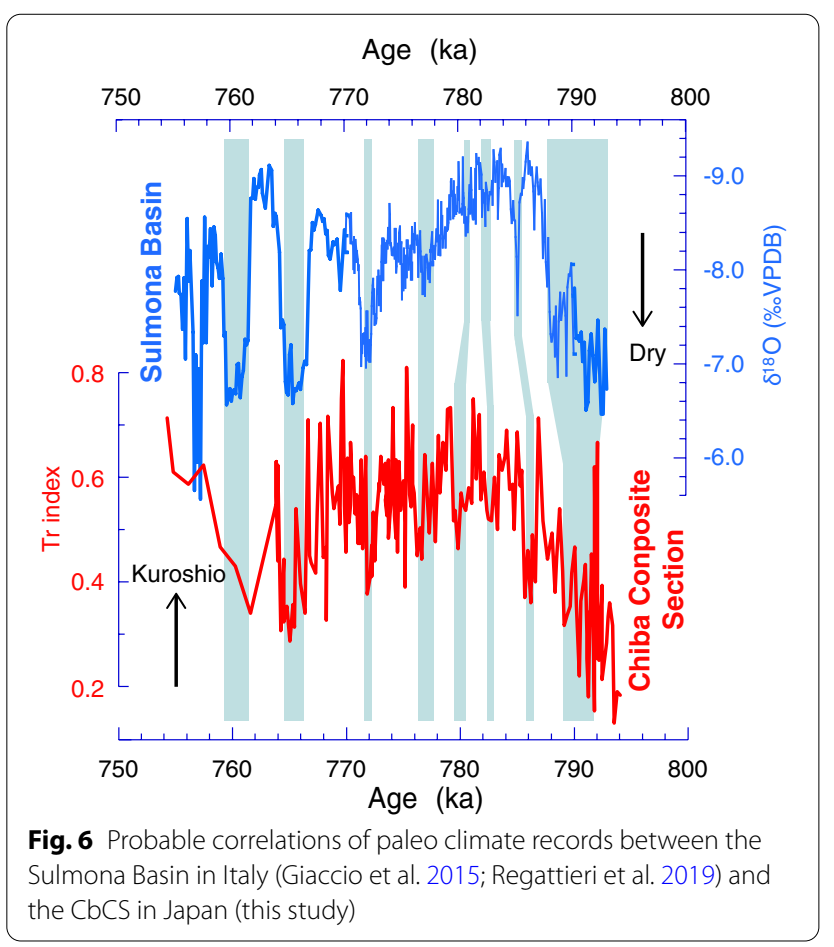


and MIS 20-19 transition were associated with Atlantic meridional overturning circulation (AMOC) disruption due to freshwater discharges into the North Atlantic.

\section{Conclusions}

Radiolarian fossil assemblages were examined using 236 samples from the CbCS including the Lower-Middle Pleistocene GSSP in the Kokumoto Formation of the Kazusa Group, central Japan. Based on a high-resolution record of abundance changes in total radiolarians and 11 species or species groups, paleoceanographic changes during MIS 20 to MIS 18 (800-750 ka) were discussed.

The Tr index, which can be used as a proxy for the relative contributions of the Kuroshio and Oyashio currents based on radiolarian assemblages, indicated the occurrence of millennial-scale oscillations in the Kuroshio-Oyashio boundary. The Tr value ranged between approximately 0.2 and 0.8 , which corresponds to the values off present day Aomori $\left(41^{\circ} \mathrm{N}\right)$ and the Boso Peninsula $\left(35^{\circ} \mathrm{N}\right)$. Except for a period during early MIS 19 , the $\operatorname{Tr}$ variations tended to be consistent with those of $\delta^{18} \mathrm{O}$ in planktonic foraminifera associated with temperature. Such inconsistencies between $\operatorname{Tr}$ and $\delta^{18} \mathrm{O}$ are likely related to differences in radiolarian ecology caused by factors such as temperature, habitat depth, stratification, and seasonal changes in production.

Multiple maxima and minima in total radiolarian production with millennial-scale periodicity during MIS 19 tended to increase with the development of the layered Kuroshio-Oyashio structure during the Kuroshio expanded mode. This is likely related to the expansion of favorable conditions for photosynthesis, such as the light environment, with warm Kuroshio water overlaying the cold Oyashio water.

Millennial-scale fluctuations in the Kuroshio-Oyashio boundary during MIS 19 can be correlated with European climate changes (Giaccio et al. 2015; Sánchez Goñi et al. 2016; Regattieri et al. 2019), and these fluctuations are thought to have emerged as a result of atmospheric circulation teleconnection over a wide area (e.g., Arctic Oscillations). However, the number of high-resolution analyses of MIS 19 is limited, and it is expected that detailed teleconnection mechanisms will be elucidated by comparing analysis results over wide geographic areas.

\footnotetext{
Abbreviations

AO: Arctic oscillations; Ca/Ti: Calcium/titanium ratio; CbCS: Chiba composite section; GSSP: Global boundary stratotype section and point; M-B boundary: Matuyama-Brunhes boundary; MIS: Marine isotope stage; NAO: North Atlantic oscillations; PC: Principal component; PCA: Principal component analysis; SST: Sea-surface temperature; TOC: Total organic carbon; $\delta^{18} \mathrm{O}$ : Oxygen isotope ratio.
}

\section{Supplementary Information}

The online version contains supplementary material available at https://doi. org/10.1186/s40645-021-00465-0.

\begin{abstract}
Additional file 1: Table $\mathbf{S} 1$. Occurrence list of radiolarians from the CbCS that are newly reported in this study.
\end{abstract}

Additional file 2: Table S2. Relative abundance (\%) of radiolarian indicator, $\operatorname{Tr}$ values, and total radiolarian abundance from the CbCS. Dataset was compiled for this study and 41 preliminary results from Suganuma et al. (2018, green hatches with italic characters). Because three samples (YN-07, YN-09, YN-05) reported by Suganuma et al. (2018) are stratigraphically overlapped with newly analyzed samples, they were excluded from the dataset.

Additional file 3: Fig. S1. (Lithologic column). Lithologic column and sampling horizon of the CbCS, modified from Suganuma et al. (2018). Stratigraphic correlation between the Urajiro, Yanagawa, Yoro River, Yoro-Tabuchi, and Kokusabata based on lithology and tephra beds are indicated by black dashed and red solid lines. The red solid lines especially indicate correlation points for reconstructing the age model of the TB-2 core (Additional file 4: Fig. S2).

Additional file 4: Fig. S2. Temporal profile of low field magnetic susceptibility and Ca/Ti. Black solid lines and circles are data from the CbCS (Okada et al. 2017; Simon et al. 2019; Izumi et al. 2021). Light blue lines are data from the TB-2 core (Hyodo et al. 2016, 2017), which was dated using the latest age model of the CbCS by Suganuma et al. (2018). The age model of the TB-2 core, which was drilled at $\sim 200$ m northeast from the Chiba section (Hyodo et al. 2016), was obtained by tuning the diatom assemblage record from Osaka Bay (Hyodo and Kitaba 2016; Hyodo et al. 2017), whereas the chronology of the CbCS is based on tuning the benthic foraminifera oxygen isotope record to an astronomically dated sea level record from ODP 1123 (Elderfield et al. 2012; Suganuma et al. 2018). The difference in chronology hinders comparisons of paleoenvironmental records between the CbCS and TB-2 core. To resolve this issue, we converted the depth scale of the TB-2 core to the age scale of the CbCS using the latest age model by Suganuma et al. (2018) based on correlating six tephra beds and one upper limit of the mud crust bed (Additional file 3: Fig. S1). Resultant temporal profiles of $\mathrm{Ca}$ /Ti ratio and low-field magnetic susceptibility of the TB-2 core show excellently synchronized variation with those of the CbCS (this S. Fig.; Hyodo et al. 2016, 2017; Okada et al. 2017; Simon et al. 2019; Izumi et al. 2021). This indicates that the tephrostratigraphic and lithologic correlation allows us to compare the paleoenvironmental records between the CbCS and TB-2 core.

Additional file 5: Fig. S3. Plot showing the latitudinal distribution of radiolarian species or species groups used to estimate the $T r$ index in the northwestern Pacific based on the dataset from Matsuzaki and Itaki (2017).

Additional file 6: Fig. S4. Results of spectral analysis (simple periodogram) for $\delta^{18} \mathrm{O}$ of $G$. bulloides (180_Gb), Tr index, and total radiolarian analysis using the PAST statistical software package (Hammer et al. 2001). The three-point moving average data was processed through the regular interpolation for spacing and a bandpass filter from 0.03 to 0.4 .

\section{Acknowledgements}

We express our sincere gratitude to all members of the GSSP proposal for Chiba section samples. Noritoshi Suzuki provided useful advice regarding radiolarian ecology. We are also grateful to Hitomi Yamazaki for assistance with conducting laboratory experiments.

\section{Authors' contributions}

$\mathrm{TI}$ conceived the experiments and wrote the manuscript. TI and SU conducted the experiments. $\mathrm{YH}, \mathrm{Kl}$, and $\mathrm{YK}$ contributed to determining geochemical proxies and their interpretation. YH, YS, and MO contributed to stratigraphic correlation and interpretation of datasets. YH, YS, and MO conducted geological surveys and sampling. All authors agree to submission of the manuscript. 


\section{Author information}

TI is a senior researcher at the Geological Survey of Japan (GSJ), AIST, Japan; SU was a Master course student at Chiba University and an AIST research assistant, Japan (2018-2020); YH is a post-doctoral fellow at the GSJ, AIST, Japan; $\mathrm{KI}$ is an associate professor at Chiba University, Japan; YK is a researcher at the National Museum of Nature and Science, Japan; YS is an associate professor at NIPR, Japan; MO is a professor at Ibaraki University, Japan.

\section{Funding}

This work was supported by JSPS KAKENHI Grant Numbers $16 \mathrm{H04068}$ and $19 \mathrm{H} 00710(\mathrm{MO})$

\section{Availability of data and materials}

The datasets supporting the conclusions of this paper are available as additional files (Additional file 1: Table S1).

\section{Declarations}

\section{Competing interests}

The authors declare that they have no competing interests.

\section{Author details}

${ }^{1}$ Geological Survey of Japan/AIST, Institute of Geoinformation and Geology, 1-1-1 Hihashi, Tsukuba, Ibaraki 305-8567, Japan. ${ }^{2}$ Faculty and Graduate School of Education, Chiba University, 1-33 Yayoi-cho, Inage-ku, Chibashi, Chiba 263-8522, Japan. ${ }^{3}$ National Institute of Polar Research, 10-3 Midori-cho, Tachikawa, Tokyo 190-8518, Japan. ${ }^{4}$ Department of Geology and Paleontology, National Museum of Nature and Science, 4-1-1 Amakubo, Tsukuba, Ibaraki 305-0005, Japan. ${ }^{5}$ Department of Polar Science, School of Multidisciplinary Sciences, The Graduate University for Advanced Studies (SOKENDAI), Hayama, Japan. ${ }^{6}$ Department of Earth Sciences, Ibaraki University, 2-2-1 Bunkyo, Mito, Ibaraki 310-8512, Japan.

Received: 22 March 2021 Accepted: 22 December 2021

Published online: 12 January 2022

\section{References}

Bjørklund KR (1974) The seasonal occurrence and depth zonation of radiolarians in Korsfjorden, western Norway. Sarsia 56:13-42

Chinzei K, Fujioka K, Kitazato H, Koizumi I, Oba T, Oda M, Okada H, Sakai T, Tanimura Y (1987) Postglacial environmental change of the Pacific Ocean off the coasts of central Japan. Mar Micropaleontol $11(4): 273-291$

Deser C, Alexander MA, Timlin MS (1999) Evidence for a wind-driven intensification of the Kuroshio Current Extension from the 1970s to the 1980s. J Clim 12:1697-1706

Elderfield H, Ferretti P, Greaves M, Crowhurst S, McCave IN, Hodell D, Piotrowski AM (2012) Evolution of ocean temperature and ice volume through the mid-Pleistocene climate transition. Science 337:704-709. https://doi.org/ 10.1126/science.1221294

Ferretti P, Crowhurst AJ, Naafs BDA, Barbante C (2015) The Marine Isotope Stage 19 in the mid-latitude Northern Atlantic Ocean: astronomical signature and intra-interglacial variability. Quat Sci Rev 108:95-110

Giaccio B, Regattieri E, Zanchetta G, Nomade S, Renne PR, Sprain CJ, Drysdale RN, Tzedakis PC, Messina P, Scardia G, Sposato A, Bassinot F (2015) Duration and dynamics of the best orbital analogue to the present interglacial. Geology 43:603-606. https://doi.org/10.1130/G36677.1

GSSP Proposal Group (2019) A summary of the Chiba Section, Japan: a proposal of global boundary stratotype section and point (GSSP) for the middle Pleistocene subseries. J Geol Soc Jpn 125:5-22

Hammer O, Harper D, Ryan PD (2001) PAST: paleontological statistic software package for education and data analyses. Paleontol Eletron 4:art. 4. http:// palaeo-electronica.org/2001_1/past/issue1_01.htm.

Haneda Y, Okada M, Kubota Y, Suganuma Y (2020) Millennial-scale hydrographic changes in the northwestern Pacific during marine isotope stage 19: teleconnections with ice melt in the North Atlantic. Earth Planet Sci Lett 531:115936. https://doi.org/10.1016/j.epsl.2019.115936
Head MJ (2021) Review of the early-middle Pleistocene boundary and Marine Isotope Stage 19. Prog Earth Planet Sci. https://doi.org/10.1186/ s40645-021-00439-2

Head MJ, Gibbard PL (2015) Early-Middle Pleistocene transitions: linking terrestrial and marine realms. Quat Int 389:7-46. https://doi.org/10.1016/j. quaint.2015.09.042

Hodell DA, Channell JET, Curtis JH, Romero OE, Röhl U (2008) Onset of "Hudson Strait" Heinrich events in the eastern North Atlantic at the end of the middle Pleistocene transition ( 640 ka)? Paleoceanography 23:PA4218. https://doi.org/10.1029/2008PA001591

Hyodo M, Kitaba I (2016) Timing of the MatuyamaeBrunhes geomagnetic reversal: decoupled thermal maximum and sea-level highstand during Marine Isotope Stage 19. Quat Int 383:136-144. https://doi.org/10.1016/j. quaint.2015.01.052

Hyodo M, Katoh S, Kitamura A, Takasaki K, Matsushita H, Kitaba I, Tanaka I, Nara M, Matsuzaki M, Dettman DL, Okada M (2016) High resolution stratigraphy across the early-middle Pleistocene boundary from a core of the Kokumoto Formation at Tabuchi, Chiba Prefecture, Japan. Quat Int 397:16-26. https://doi.org/10.1016/j.quaint.2015.03.031

Hyodo M, Bradák B, Okada M, Katoh S, Kitaba I, Dettman DL, Hayashi H, Kumazawa K, Hirose K, Kazaoka O, Shikoku K, Kitamura A (2017) Millennial-scale northern Hemisphere Atlantic-Pacific climate teleconnections in the earliest Middle Pleistocene. Sci Rep 7:10036. https://doi.org/10. 1038/s41598-017-10552-2

Isono D, Yamamoto M, Irino T, Oba T, Murayama M, Nakamura T, Kawahata H (2009) The 1500-year climate oscillation in the midlatitude North Pacific during the Holocene. Geology 37:591-594. https://doi.org/10.1130/ G25667A

Itaki T (2009) Last glacial to Holocene polycystine radiolarians from the Japan Sea. News Osaka Micropaleontol (NOM) 14:43-89

Itaki T, Minoshima K, Kawahata H (2008) Radiolarian flux at an IMAGES site at the western margin of the subarctic Pacific and its seasonal relationship to the Oyashio Cold and Tsugaru Warm currents. Mar Geol 255:131-148

Itaki T, Sagawa T, Kubota Y (2018) Data report: Pleistocene radiolarian biostratigraphy, IODP Expedition 346 Site U1427. In: Tada R, Murray RW, Alvarez Zarikian CA, the Expedition 346 Scientists (eds) Proceedings of the integrated ocean drilling program, vol 346. Integrated Ocean Drilling Program, College Station, TX. https://doi.org/10.2204/iodp.proc.346.202. 2018

Izumi K, Haneda Y, Suganuma Y, Okada M, Kubota Y, Nishida N, Kawamata M, Matsuzaki T (2021) Multiproxy sedimentological and geochemical analyses across the lower-middle Pleistocene boundary: chemostratigraphy and paleoenvironment of the Chiba composite section, central Japan. Prog Earth Planet Sci 8:10. https://doi.org/10.1186/s40645-020-00393-5

Jouzel J, Masson-Delmotte V, Cattani O, Dreyfus G, Falourd S, Hoffmann G, Minster B, Nouet J, Barnola JM, Chappellaz J, Fischer H, Gallet JC, Johnsen S, Leuenberger M, Loulergue L, Luethi D, Oerter H, Parrenin F, Raisbeck G, Raynaud D, Schilt A, Schwander J, Selmo E, Souchez R, Spahni R, Stauffer B, Steffensen JP, Stenni B, Stocker TF, Tison JL, Werner M, Wolff EW (2007) Orbital and millennial Antarctic climate variability over the past 800,000 years. Science 317:793-796. https://doi.org/10.1126/science.1141038

Kameo K, Kubota Y, Haneda Y, Suganuma Y, Okada M (2020) Calcareous nannofossil biostratigraphy of the lower-middle Pleistocene boundary of the GSSP, Chiba composite section in the Kokumoto Formation, Kazusa Group, central Japan, and implications for sea-surface environmental changes. Prog Earth Planet Sci 7:36. https://doi.org/10.1186/ s40645-020-00355-x

Kazaoka O, Suganuma Y, Okada M, Kameo K, Head MJ, Yoshida T, Kameyama S, Nirei H, Aida N, Kumai H (2015) Stratigraphy of the Kazusa Group, Central Japan: a high-resolution marine sedimentary sequence from the lower to middle Pleistocene. Quat Int 383:116-135

Kleiven HF, Hall IR, McCave IN, Knorr G, Jansen E (2011) Coupled deep-water flow and climate variability in the Middle Pleistocene North Atlantic. Geology 39:343-346. https://doi.org/10.1130/G31651.1

Koizumi I (2008) Diatom-derived SSTs (Td' ratio) indicate warm seas off Japan during the middle Holocene (8.2-3.3 kyr BP). Mar Micropal 69:263-281

Kono T, Foreman M, Chandler P, Kashiwai M (2004) Coastal Oyashio south of Hokkaido, Japan. J Phys Oceanogr 34:1477-1494

Kubota Y, Haneda Y, Kameo K, Itaki T, Hayash H, Shikoku K, Izumi K, Head MJ, Suganuma Y, Okada M (2021) Paleoceanography of the northwestern 
Pacific across the early-middle Pleistocene boundary (Marine Isotope Stages 20-18). Prog Earth Planet Sci 8:29. https://doi.org/10.1186/ s40645-020-00395-3

Matsuzaki KM, Itaki T (2017) New Northwest Pacific radiolarian data as a tool to estimate past sea surface and intermediate water temperatures. Paleoceanogr Paleoclimatol 32(3):218-245. https://doi.org/10.1002/2017P A003087

Matsuzaki K, Itaki T, Sugisaki S (2020) Polycystine radiolarians vertical distribution in the subtropical Northwest Pacific during Spring 2015 (KS15-4). Paleontol Res 24:113-133. https://doi.org/10.2517/2019PR019

Motoyama I, Itaki T, Kamikuri S, Taketani Y, Okada M (2017) Cenozoic biostratigraphy, chronostratigraphy and paleoceanography in the Boso Peninsula and Bandai Volcano in the Aizu region, East Japan. Sci Rep Niigata Univ (geology) 32(Supplement):1-27

Nigrini C (1970) Radiolarian assemblages in the North Pacific and their application to a study of quarternary sediments in core V20-130. Geol Soc Am Mem 126:39-175. https://doi.org/10.1130/MEM126-p139

Nishibe Y, Takahashi K, Shiozaki T, Kakehi S, Saito H, Furuya K (2015) Sizefractionated primary production in the Kuroshio Extension and adjacent regions in spring. J Oceanogr 71:27-40

Nishida N, Kazaoka O, Izumi K, Suganuma Y, Okada M, Yoshida T, Ogitsu I, Nakazato H, Kameyama S, Kagawa A, Morisaki M, Nirei H (2016) Sedimentary processes and depositional environments of a continuous marine succession across the Lower-Middle Pleistocene boundary: Kokumoto Formation, Kazusa group, central Japan. Quat Int 397:3-15

Nishikawa H, Usui N, Kamachi M, Tanaka Y, Ishikawa Y (2016) Link between the interannual variability in the Kuroshio-Oyashio layered structure and the chlorophyll-a concentrations in the Kuroshio Extension during spring. Oceanogr Jpn 25(5):133-144 ((in Japanese with English abstract))

Nomade S, Bassinot F, Marino M, Simon Q, Dewilde F, Maiorano P, Isguder G, Blamart D, Girone A, Scao V, Pereira A, Toti F, Bertini A, CombourieuNebout N, Peral M, Bourles DL, Petrosino P, Gallicchio S, Ciaranfi N (2019) High-resolution foraminifer stable isotope record of MIS 19 at Montalbano Jonico, southern Italy: a window into Mediterranean climatic variability during a low-eccentricity interglacial. Quat Sci Rev 205:106-125. https://doi.org/10.1016/j.quascirev.2018.12.008

Okada M, Suganuma Y, Haneda Y, Kazaoka O (2017) Paleomagnetic direction and paleointensity variations during the Matuyama-Brunhes polarity transition from a marine succession in the Chiba composite section of the Boso Peninsula, central Japan. Earth Planets Space. https://doi.org/10. 1186/s40623-017-0627-1

Okazaki Y, Takahashi T, Onodera J, Honda MC (2005) Temporal and spatial flux changes of radiolarians in the northwestern Pacific Ocean during 1997-2000. Deep-Sea Res II 52:2240-2274

Prokopenko AA, Hinnov LA, Williams DF, Kuzmin MI (2006) Orbital forcing of continental climate during the Pleistocene: a complete astronomically tunedclimatic record from Lake Baikal, SE Siberia. Quat Sci Rev 25:3431-3457. https://doi.org/10.1016/j.quascirev.2006.10.002

Regattieri E, Giaccio B, Mannella G, Zanchetta G, Nomade S, Tognarelli A, Perchiazzi N, Vogel H, Boschi C, Drysdale RN, Wagner B, Gemelli M, Tzedakis P (2019) Frequency and dynamics of millennial-scale variability during Marine Isotope Stage 19: insights from the Sulmona Basin (central Italy). Quat Sci Rev 214:28-43. https://doi.org/10.1016/j.quascirev.2019.04.024

Sagawa T, Kuroyanagi A, Irino T, Kuwae M, Kawahata H (2013) Seasonal variations in planktonic foraminiferal flux and oxygen isotopic composition in the western North Pacific: implications for paleoceanographic reconstruction. Mar Micropaleontol 100:11-20. https://doi.org/10.1016/j. marmicro.2013.03.013

Sánchez Goñi MF, Rodrigues T, Hodell DA, Polanco-Martínez JM, Alonso-García M, Hernández-Almeida I, Desprat S, Ferretti P (2016) Tropically-driven climate shifts in southwestern Europe during MIS19, a low eccentricity inter-glacial. Earth Planet Sci Lett 448:81-93. https://doi.org/10.1016/j. epsl.2016.05.018

Simon Q, Bourles DL, Bassinot F, Nomade S, Marino M, Ciaranfi N, Girone A, Maiorano P, Thouveny N, Choy S, Dewilde F, Scao V, Isguder G, Blamart D (2017) Authigenic ${ }^{10} \mathrm{Be} /{ }^{9} \mathrm{Be}$ ratio signature of the MatuyamaeBrunhes boundary in the Montalbano Jonico marine succession. Earth Planet Sci Lett 460:255-267. https://doi.org/10.1016/j.epsl.2016.11.052

Simon Q, Suganuma Y, Okada M, Haneda Y, ASTER Team (2019) High-resolution $10 \mathrm{Be}$ and paleomagnetic recording of the last polarity reversal in the
Chiba composite section: age and dynamics of the Matuyama-Brunhes transition. Earth Planet Sci Lett 519:92-10

Suganuma Y, Okada M, Horie K, Kaiden H, Takehara M, Senda R, Kimura J, Haneda Y, Kawamura K, Kazaoka O, Head MJ (2015) Age of MatuyamaBrunhes boundary constrained by U-Pb zircon dating of a widespread tephra. Geology 43:491-494

Suganuma Y, Haneda Y, Kameo K, Kubota Y, Hayashi H, Itaki T, Okuda M, Head MJ, Sugaya M, Nakzato H, Igarashi A, Shikoku K, Hongo M, Watanabe M, Satoguchi Y, Takeshita Y, Nishida N, Izumi K, Kawamura K, Kawamata M, Okuno J, Yoshida T, Ogitsu I, Yabusaki H, Okada M (2018) Paleoclimatic and paleoceanographic records of Marine Isotope Stage 19 at the Chiba composite section, central Japan: a reference for the early-middle Pleisotocene boundary. Quat Sci Rev 191:406-430. https://doi.org/10.1016/j. quascirev.2018.04.022

Tompson DWJ, Wallace JM (1998) The Arctic oscillation signature in the wintertime geopotential height and temperature fields. Geophys Res Lett 25:1297-1300

Tzedakis PC, Channell JET, Hodell DA, Kleiven HF, Skinner LC (2012) Determining the natural length of the current interglacial. Nat Geosci 5:138-141. https://doi.org/10.1038/ngeo1358

Valet JP, Bassinot F, Bouilloux A, Bourles D, Nomade S, Guillou V, Lopes F, Thouveny N, Dewilde F (2014) Geomagnetic, cosmogenic and climatic changes across the last geomagnetic reversal from Equatorial Indian Ocean sediments. Earth Planet Sci Lett 397:67-79. https://doi.org/10. 1016/j.epsl.2014.03.053

Wennrich V, Minyuk PS, Borkhodoev V, Francke A, Ritter B, Nowaczyk NR, Sauerbrey MA, Brigham-Grette J, Melles M (2014) Pliocene to Pleistocene climate and environmental history of Lake El'gygytgyn, Far East Russian Arctic, based on high-resolution inorganic geochemistry data. Clim past 10:1381-1399. https://doi.org/10.5194/cp-10-1381-2014

Yanagisawa Y (1993) Note on diatom temperature index (Td). Fossils 55:1-8 ((in Japanese with English abstract))

Yasudomi Y, Motoyama I, Oba T, Anma R (2014) Environmental fluctuations in the northwestern Pacific Ocean during the last interglacial period: evidence from radiolarian assemblages. Mar Micropaleontol 108:1-12

\section{Publisher's Note}

Springer Nature remains neutral with regard to jurisdictional claims in published maps and institutional affiliations.

\section{Submit your manuscript to a SpringerOpen ${ }^{\circ}$ journal and benefit from:}

- Convenient online submission

- Rigorous peer review

- Open access: articles freely available online

- High visibility within the field

- Retaining the copyright to your article

Submit your next manuscript at $\boldsymbol{\nabla}$ springeropen.com 